\title{
BIOCHEMICAL ALTERATIONS IN THE BLOOD, MILK AND TISSUES OF SHEEP MAMMARY GLAND AFTER EXPERIMENTAL MYCOPLASMAL MASTITIS
}

\author{
H. S. BANGA, P. P. GUPTA, S. P. AHUJA, \\ A. K. SRIVASTAVA and K. S. ROY \\ Department of Veterinary Pathology, \\ Punjab Agricultural University, Ludhiana' (India)
}

Received March 15, 1988

$A b s t r a c t$

B a $n g$ a H. S., P. P. G u p $\mathrm{a}$, S. P. A hu ja, A. K. $S r i v a s t a v a, k$. $s$. $R \circ y$ : Biochemical Alterations in the Blood, Milk and Tissues of Sheep Mammary Gland After Experimental Mycoplasmal Mastitis. Acta vet. Brno, 58, 1989: 97111.

To study the biochemical changes in milk, blood plasma and udder tissues, during unilateral mycoplasmal mastitis, 7 lactating sheep were inoculated through the right teat canal with $2 \mathrm{ml}$ of Mycoplasma mycoides sub sp. mycoides (Mmm) Large-colony type (LC) culture containing $10^{5}$ colony forming units per $\mathrm{ml}$. The left udder halves of all the sheep served as controls. One animal was killed at every third day interval up to 21 days post-inoculation.A11 the sheep developed clinical mastitis within $24 \mathrm{~h}$ after inoculation of Mycoplas $\mathrm{ma}$, which persisted till the end of the experiment. The total protein, total cholesterol, total phospholipids and free fatty acid contents of mastitic milk and mammary secretions showed progressive increase, whereas total lipids and glycerides decreased substantially. Such results indicate that Mycoplasma use lipolytic enzymes to degrade lipids to meet the needs of energy and for the biosynthesis of membrane lipid bilayer during their multiplication.

Quantitative estimations and histoenzymatic studies revealed increased activities of aspartate aminotransferase (EC 2.6.1.1), alanine aminotransferase (EC 2.6.1.2), acid phosphatase (EC 3.1.3.2), alkaline phosphatase (EC 3.1.3.1), malate dehydrogenase (EC 1.1.1.38), lactic dehydrogenase (EC 1.1.1.27), adenosine triphosphatase (EC 3.6.1.3), and amylase (EC 3.2.1.1) in blood plasma, milk and udder tissues which was partially due to increased total leukocyte counts and the Mycoplasma organisms.

Total protein, total cholesterol, phospolipids, free fatty acids, glycerides, enzymes, M. mycoides. 
It has been reported ( $\mathrm{P}$ r a $\mathrm{s}$ a et al. 1985; $\mathrm{M}$ i s $i$ et al. 1988) that Mycoplasma infection in goat udder produces spontaneous agalactia with marked reduction in the size of secretory mammary tissue and without any systemic reaction. Mycoplasma mycoides sub sp. mycoides (Mmm) Large-colony type (LC) has been reported to cause various diseases exclusively in goats ( $\mathrm{D}$ a $\mathrm{M}$ a s a et al. 1983) and infection of sheep with this Mycoplasma appears to be rare, especially mastitis in sheep due to $\mathrm{Mmm}$ LC has not been reported. The present work was therefore undertaken to study alterations in milk, blood plasma and udder composition and the activities of their enzymes during experimentally produced mycoplasmal mastitis in sheep and with a view to assess the pathogenicity of Mmm LC to lactating sheep udder.

\section{Materials and Methods}

Seven lactating sheep aged 2.5 to 3 years were observed for 7 days preexperimentally. All were found healthy and free of sub-clinical mastitis. The total leucocyte count (TLC) of milk varied from 0.25 to $0.35 \times 10^{6} \mathrm{ml}^{-1}$. The milk was free from infectious agents. Two $\mathrm{ml}$ of $48 \mathrm{~h}$ culture of $\mathrm{Mmm}$ LC at third passage level, containing $10^{5}$ colony forming units (CFU).ml ${ }^{-1}$ was inoculated through the right teat canal into the right half of udder of all the 7 sheep and their left halves were inoculated with $2 \mathrm{~m} 1$ of sterile mycoplasma broth to serve as control. Any abnormalities in udder, temperature, systemic disturbances and mastitis (assessed by California mastitis test and modified Whiteside test) were recorded. Samples of milk/mammary secretions were obtained from all the sheep before inoculation and at every third day interval up to twentyone days after infection (DAI). These were cultured on mycoplasma medium ( $\mathrm{a}$ $\mathrm{e} r \mathrm{j}$ e e et al. 1979), blood agar and Saboraud $s$ Dextrose agar. Total leucocyte (TLC) of milk/mammary secretions and haematological value of sheep were also recorded. The pooled milk/mammary secretions were analysed for total lipids (F $\circ 1 \mathrm{ch}$ et al. 1957), total phospholipids (A m e s 1966), total cholesterol ( $\mathrm{Z} 1 \mathrm{a} \mathrm{t} \mathrm{k} \mathrm{i}$ and $\mathrm{Z}$ a $\mathrm{k}$ 1969), total free fatty acids (L $\circ$ w $\mathrm{y}$ and $\mathrm{T}$ i n s 1 e y 1976), total glycerides (by difference) and total proteins (G $\circ \mathrm{r}$ n a 11 et al. 1949). Estimations of various enzymes in milk and udder tissues was done by following the methods described by $\mathrm{W} \circ$ o $\mathrm{t} t$ o $\mathrm{n}$ (1964). Blood plasma samples were analysed for alanine aminotransferase (ALT), aspartate aminotransferase (AST), acid phosphatase (ACP), alkaline phosphatase (ALP), lactic dehydrogenase (LDH), malate dehydrogenase $(\mathrm{MDH})$, adenosine triphosphatase (ATPase), amylase and creatinine ( $\mathrm{W} 0 \mathrm{t} \mathrm{t} \circ \mathrm{n} 1964)$.

The experiment was continued for 21 days. One animal was killed at every 3rd day interval i.e. up to twentyone days after infection. Udders and their lymph nodes were examined grossly and microscopically. For microscopic examination 5 to $6 \mu$ thick paraffin sections were stained with haematoxylin and eosin. Cryostat sections of the udder tissues were used for histochemical and histoenzymic studies (B a r k a and A n d e r s o 1963).

Results

Body temperature was increased transitorily from third to sixth DAI without affecting the appetite. The infected 


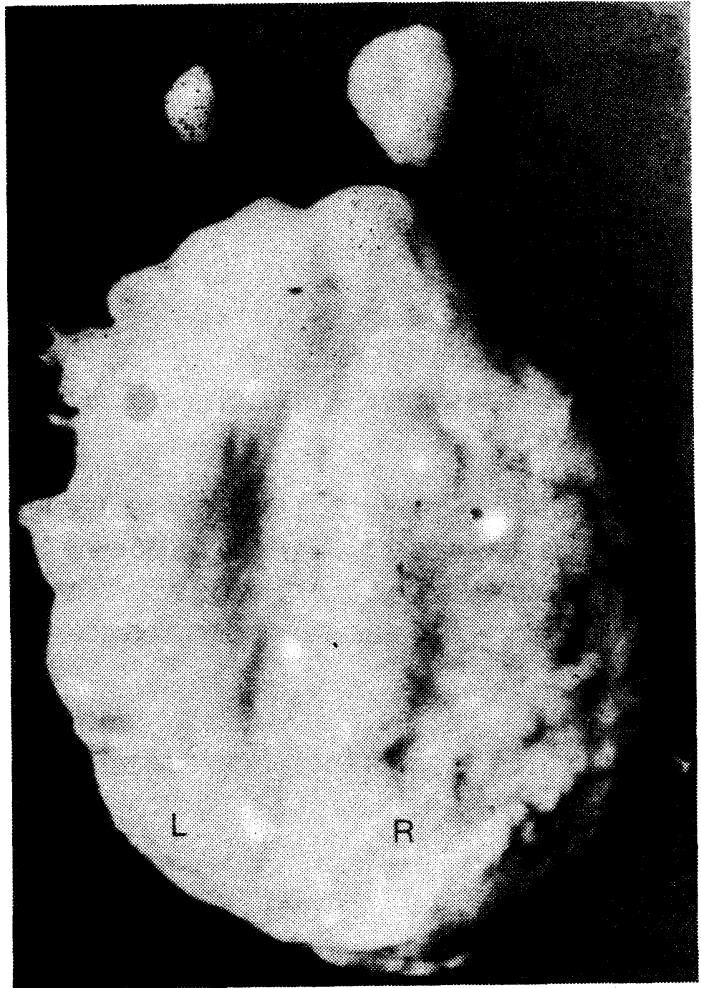

Fig. 1. Increase in the size of right udder half ( $R$ ) and its corresponding lymph node 21 days after inoculation with $M_{\text {. }}$ mycoides sub sp. mycoides Large-colony type.

udder halves of all the 7 sheep were inflammed, hot, tender and painful at second DAI and remained enlarged (Fig. 1) throughout the experiment. Between day 3 and 21 post infection there was a marked decrease in the volume of milk/mammary secretions from the right infected halves and the secretions were yellowish, thick, turbid with shreds of blood and on standing, the proteins settled down as aggregates leaving clear whey-like fluid. On the other hand, there was only slight change in colour, consistency and amount of milk drawn from moninfected left udder halves. Mastitis in the right infected halves was severe (Fig. 2) from 2nd DAI to 21st DAI.

The total leucocyte counts of milk from infected halves increased from the basal value of $0.30 \times 10^{6} \cdot \mathrm{ml}^{-1}$ to $2.14 \mathrm{x}$ 


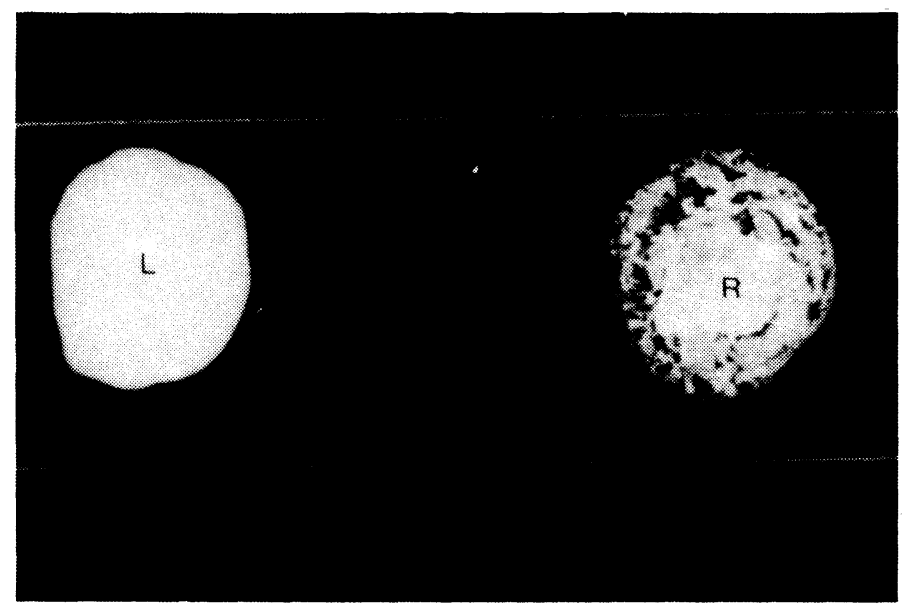

Fig. 2. Right(R)-Milk from right infected udder half showing severe positive reaction with modified Whiteside test. Left(L)-Milk from left control udder half of the same animal was negative for mastitis test.

$\times 10^{6} \cdot \mathrm{ml}^{-1}$ on 3 rd DAI, $17.4 \times 10^{6} \cdot \mathrm{ml}^{-1}$ on 6 th DAI and $27.8 \times 10^{6} \cdot \mathrm{ml}^{-1}$ on the 9th DAI.

Thereafter these values decreased gradually $(18.8 \times$ $\times 10^{6} \cdot \mathrm{ml}^{-1}, 13.1 \times 10^{6} \cdot \mathrm{ml}^{-1}, 8.7 \times 10^{6} \cdot \mathrm{ml}^{-1}$ and $2 \times 10^{6} \cdot \mathrm{ml}^{-1}$ on 12 th, 15th, 18th and 21 st DAI, respectively) but remained much higher than the basal values. Leucocyte counts of milk from noninfected left halves were unaffected. The total leucocyte counts of blood increased from the basal value of $6.4 \times 10^{3} \cdot \mathrm{cmm}^{-1}$ to $12 \times 10^{3} \cdot \mathrm{cmm}^{-1}$ on 15 th DAI. There was a gradual decrease of haemoglobin content also.

Mmm LC was re-isolated from mammary secretions of all the right infected udder halves up till 18th DAI, but not from the milk of noninfected udder halves. No bacteria or fungal agent was detected in the milk of any sheep during the experiment.

Microscopically, the infected udder halves of sheep killed on 3rd and 6th DAI showed acute diffuse purulent mastitis characterised by marked infiltration of neutrophils in the lumina of acini (Fig. 3) and vacuolar degeneration of epithelial cells lining the acini. The animals killed on 9th, 12th, 15th, 18th and 21st DAI showed chronic interstitial mastitis. Atrophied acini, proliferated fibrous connective 


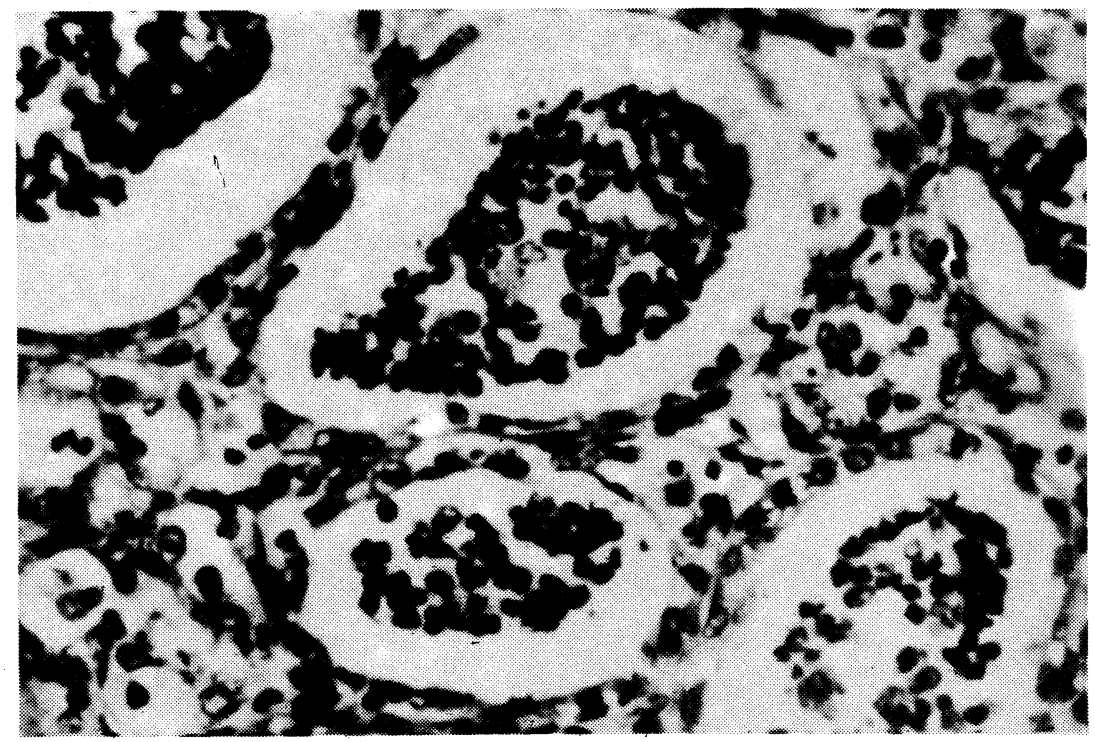

Fig. 3. Section of right infected udder half of sheep killed on 3rd day after infection showing acute diffuse purulent mastitis characterised by marked infiltration of neutrophils in the lumina of acini. H. E. X 300 .

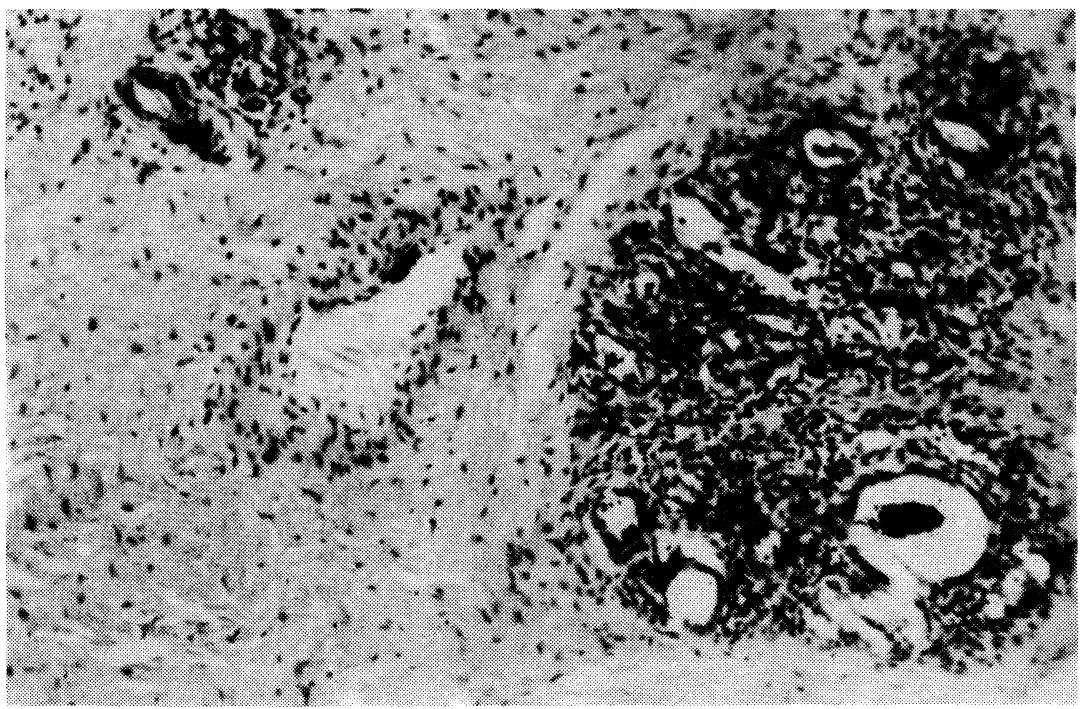

Fig. 4. Section of right udder half of sheep killed on 21st day after infection showing chronic mastitis with intense fibrosis replacing the glandular parenchyma. H. E. X 70. 

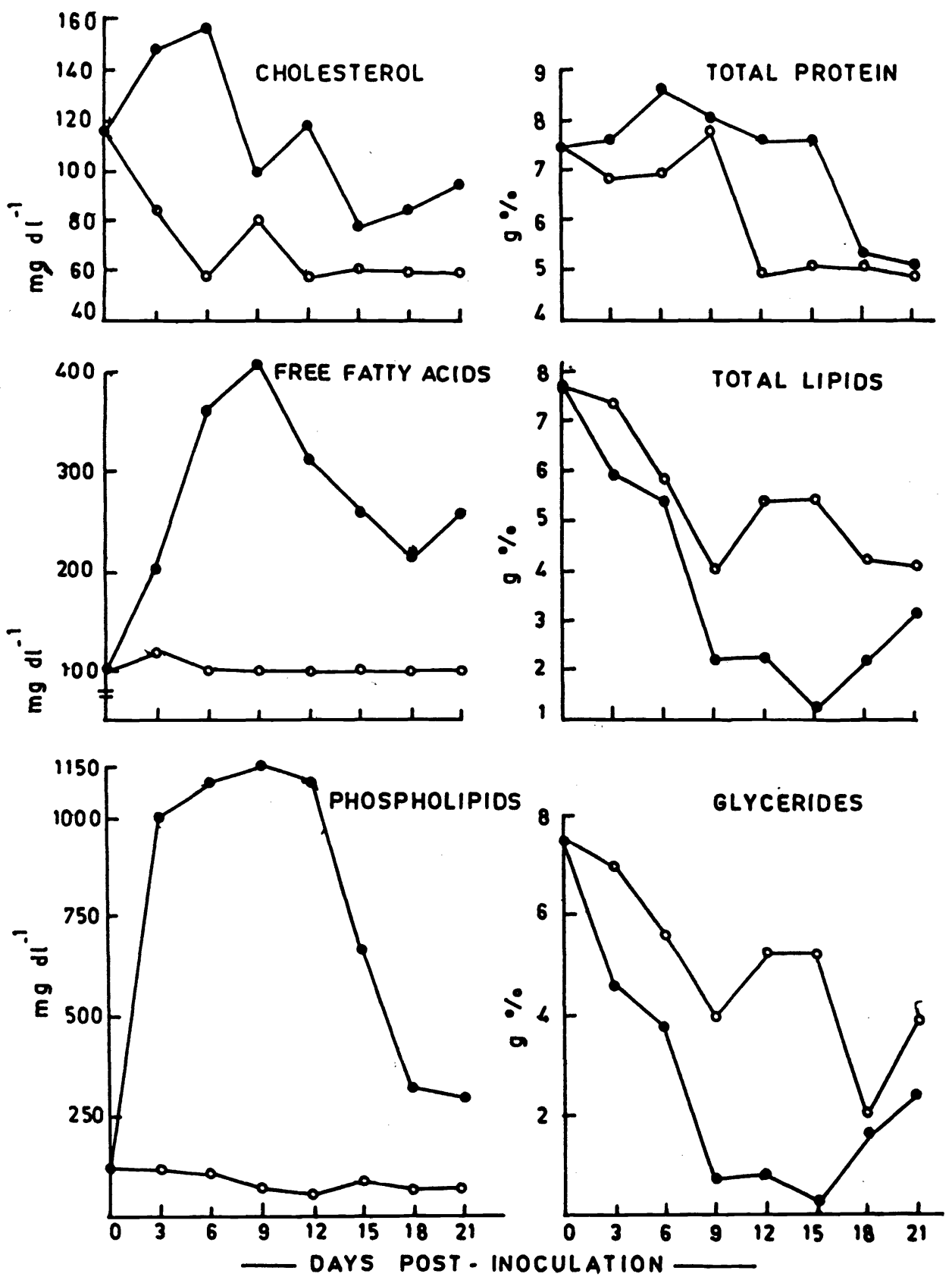

Fig. 5. Changes in the composition of cholesterol, free fatty acids, phospholipids, total protein, total lipids and glycerides in mammary secretions from control $0_{-O}$ and inoculated udder halves of sheep. 
tissue (Fig. 4), thickening of interlobular septa, chronic galactophoritis with squamous metaplasia of the lining epithelium and marked infiltration of lymphocytes were observed. The mammary lymph nodes of infected udder halves showed reactive lymphadenitis. There was no pathological change in the non-infected udder halves and their lymph nodes.

The total protein, total cholesterol, total phospholipids and free fatty acid content of mastitic mammary secretions, from infected udder halves increased markedly after infection and remained higher than those in the milk from left control halves throughout the experiment (Fig. 5). The total lipids and glycerides content were decreased substantially (Fig. 5). Esterification of cholesterol was higher in mastitic milk/mammary secretions from infected udder halves as compared to the control left halves.

In blood plasma, gradual increase in the levels of ALT, AST, ALP, ACP, LDH, MDH, ATPase and amylase was observed without any appreciable change in the levels of creatinine (Fig. 6). In milk, increased activities of AST, ALT, ALP, ACP, and ATPase were observed from both infected and control udder halves throughout the experiment but the increase was more marked in the right infected halves. There was no significant change in the amylase levels in milk either from the right or left udder halves (Fig. 7a).

The AST, ALT, ACP, ALP, LDH and ATPase increased gradually in the tissues of both udder halves after inoculation of Mycoplasma but increase in these enzymes was more marked (about 2 times) in the right infected halves than those in left halves (Fig. 7b). Histoenzymic studies also revealed increase in the activities of ALP, ACP, LDH and succinic dehydrogenase $(\mathrm{SDH})$ in the infected right udder halves.

\section{Discussion}

This study clearly indicated that Mycoplasma mycoides sub sp. mycoides (Mmm) Large-colony type (LC) was highly pathogenic to sheep udder and caused mastitis by damaging the udder tissue. These effects have been reported to be due to binding of Mycoplasma to secretory cells leading to their death by peroxide, nucleases and toxic metabolites 

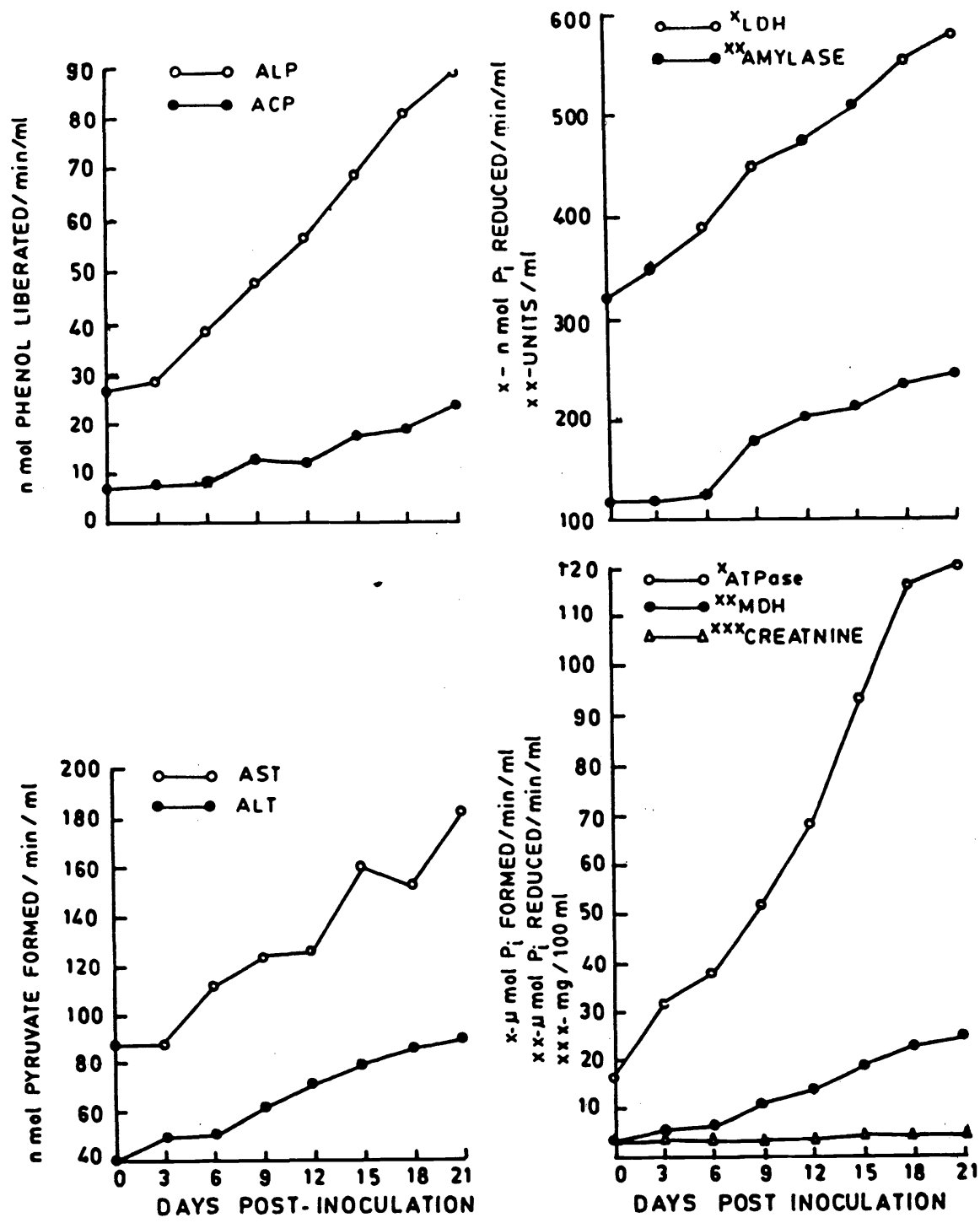

Fig. 6. Changes in the levels of creatinine and enzymes in blood of sheep administered Mycoplasma in the right half of the udder.

( C h e r r y and $T$ a y lor $R$ o b i n s o $n$ 1970).

The re-isolation of Mmm LC from milk/mammary secretions even eighteen DAI confirmed that the mastitis was of mycoplasmal origin. The increased TLC in milk and other gross and microscopic changes in udder of sheep observed in this study were similar to those described in contagious agalactia caused by $\mathrm{M}$. agalactiae $(\mathrm{H}$ e i d r i c h and 
R e n k 1967; $B$ a $r-M$ o $h$ e and $R$ a p a p o r t 1978; $\mathrm{C}$ o $\mathrm{t}$ t e w 1979; $\mathrm{B}$ a $\mathrm{r}$ t $\mathrm{n}$ and $\mathrm{C}$ o $\mathrm{t}$ e w 1980), and in experimental mastitis in sheep caused by M. canadense ( $\mathrm{B}$ a $1 \mathrm{l}$ and $\mathrm{M}$ a c k i e 1986), animal ureaplasmas ( $\mathrm{B}$ a $1 \mathrm{l}$ and $\mathrm{M}$ a c $\mathrm{k}$ i e $1985 \mathrm{ab}$ ), $\mathrm{M}$. ovipneumoniae ( $\mathrm{J} \circ \mathrm{n}$ e 1985), in goats inoculated with M. putrefaciens (A d l e r et al. 1980), M. agalactiae $\overline{\text { sub sp. bovis }}(\mathrm{O} \mathrm{j}$ o and $\mathrm{I} k \mathrm{e} \mathrm{d}$ e 1976), M. bovigenitalium ( $P$ a 1 et al. 1983), M. arginini $(P \bar{r}$ a s ad et al. 1985), M. mycoides sub sp. capri ( $M$ i s $r$ i et al. 1988) and in cows inoculated with $M$. bovis ( $B$ e $n$ e $t$ and $J$ a s p e r 1978; M e s z á r o s et al. 1986).

The lipid changes indicated increased cellular content of mycoplasma, as well as leucocytes and mycoplasmal lipase activity in the milk. Cryostat sections stained with Oil-Red-O, also showed less neutral lipid in the infected right udder halves. These biochemical and histochemical changes are similar to those reported by $M$ i $s$ i et al. (1988) in caprine experimental mastitis due to $M$. mycoides sub sp. capri. The nonspecific lipase showing optimum activity in alkaline $\mathrm{pH}$ range has been observed in some species of Mycoplasma ( $\mathrm{m} \mathrm{i} \mathrm{th}$ 1979). The increase in cholesterol content indicated hydrolysis of cholesterol esters by Mycoplasma for incorporation of cholesterol into its own membranes. The presence of sterol esterase has also been demonstrated in $M$. arthritidis,

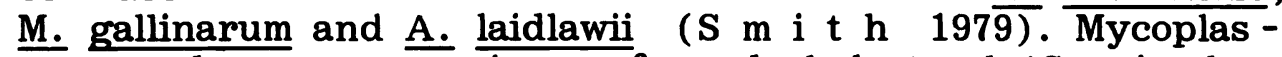
mas are known to require preformed cholesterol ( $\mathrm{S} \mathrm{m} \mathrm{t} \mathrm{h}$ 1979), therefore they may depend upon cholesterol present in mammary secretions for incorporation into their own membranes during their multiplication. The increase in total phospholipids and protein content of mastitic milk/mammary secretions may be due to higher content of membranous material either from Mycoplasma and/or inflammatory cells. The latter might also be due to albuminous secretions induced by Mycoplasma infection (S c h a $1 \mathrm{~m} \mathrm{1977).}$

Although an effect of bacterial mastitis on composition of mammary secretions of sheep has been reported ( $\mathrm{A}$ g a r a l and $\mathrm{N}$ a $\mathrm{r}$ a y a $\mathrm{n} 1976$; M a n d a 1 et al. 1977 and $M$ a $n d a l$ and $R$ a $h$ e $j$ 1985) yet such information with regard to Mycoplasma-induced mastitis in sheep is not available. An increase in free fatty

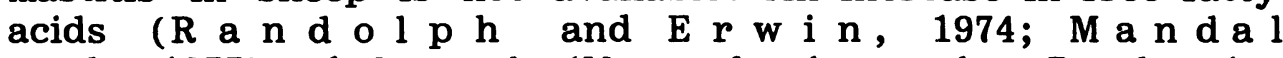
et al., 1977), cholesterol (M a n d l and $R$ a h e ja 

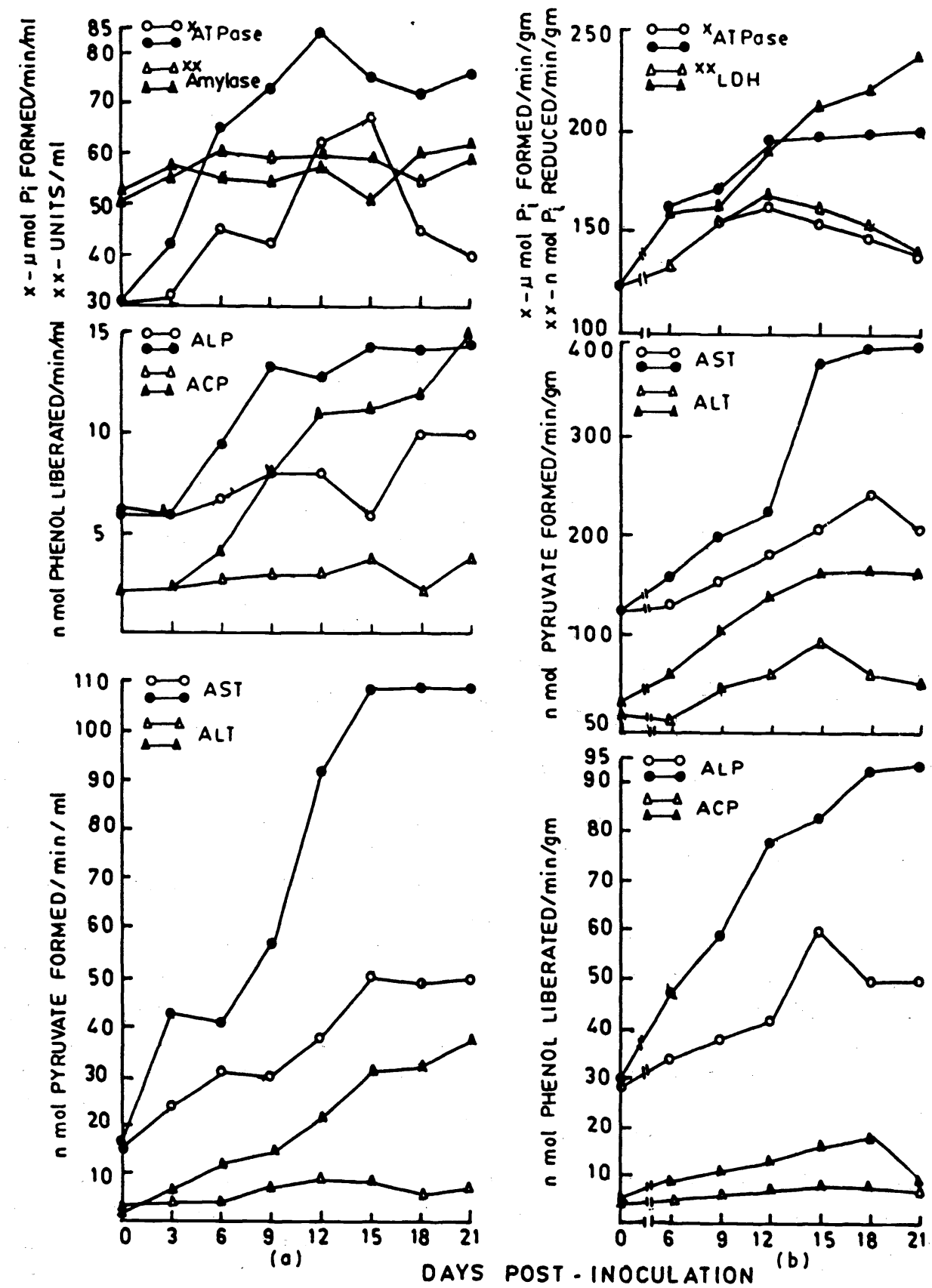

Fig. 7 Changes in the levels of various enzymes in mammary secretions (a) and tissues (b) from control $(0-0, \Delta-\Delta)$ and inoculated $(\longrightarrow$, $\stackrel{\sim}{\longrightarrow}$ ) udder halves of sheep. 
1985), phospholipids ( $\mathrm{g}$ a $\mathrm{r}$ w a 1 and $\mathrm{N}$ a $\mathrm{r}$ a y $\mathrm{n}$ a $\mathrm{n}$ 1976) and decrease in total lipids/glycerides ( $\mathrm{M}$ a $\mathrm{n} \mathrm{d}$ a 1 and $A \mathrm{~h} \mathrm{u} \mathrm{j}$ a 1985) has been reported after bacterial infection. Such reports and findings of $M$ i s $r$ et al. (1988) in experimental mastitis in goats due to $M$. mycoides sub sp. capri, and the results of the present study indicate that mastitis due to bacteria or Mycoplasma generally cause hydrolysis of milk glycerides and catabolise the released fatty acids for their anabolic needs.

Increase in the levels of ALT and AST in plasma and an appreciable increase in the levels of ACP, in udder tissues, blood plasma and milk have been reported to indicate acute or chronic tissue damage ( $W$ i l s o $n$ 1970). Increased activity of ALP enzyme in udder might be due to marked aggregation of neutrophils ( $H \circ r n$ et al. 1964; J a i $n$ 1968) and due to damage to udder tissues ( $\mathrm{K}$ a $\mathrm{n}$ e $\mathrm{k} O \mathrm{1980}$ ). Increased activities of LDH and SDH in infected udders indicate increased glycolysis ( $\mathrm{L}$ e $\mathrm{h} \mathrm{n}$ i $\mathrm{n}$ e $\mathrm{r}$ 1982). B $\mathrm{og} \mathrm{i} \mathrm{n}$ et al. (1976) also reported increased activity of LDH in bovine udder tissue during acute or chronic mastitis. The increase in amylase in blood plasma, and ATPase levels in plasma and udder tissue might have increased to meet the increased demand for supply of energy.

Mycoplasma mycoides sub sp. mycoides Large-colony type, although thought to be infective exclusively in goats, was found to be highly pathogenic to lactating sheep udder. It produced severe mastitis, with extensive damage to secretory tissue of udder which led to agalactia.

Biochemické změny $\mathrm{v}$ krevní plazmě, mléce a ve tkáních mléčné žlázy ovcí po experimentální infekci

Mycoplasma mycoides

Biochemické změny $v$ krevní plazmě, mléce a tkáních mléčné žlázy byly sledovány u 7 laktujících ovcí s unilaterální mastitidou, vyvolanou experimentálně aplikací $2 \mathrm{ml}$ kultury Mycoplasma mycoides subsp. mycoides (Mmm) typu velkých koloní (LC) s obsahem $10^{5}$ buněk schopných reprodukce (CFU) v $1 \mathrm{ml}$. Kultura M. mycoides byla vpravena do strukového kanálku pravé poloviny mléčné žlázy. Její levá polovina sloužila jako kontrolní. Každý 3 . den po inokulaci 
až do 21 . dne bylo utraceno 1 zvír̆e. U všech ovcí se vyvinula klinická mastitida do $24 \mathrm{~h}$ po inokulaci a přetrvávala do konce poku su. Koncentrace celkových bílkovin, celkového cholesterolu, fosfolipidů a volných mastných kyselin v mléce (resp. sekretu mléčné žlázy) progresivně stoupala, zatímco koncentrace ce lkových lipidů a glyceridů výrazně poklesla. Tyto výsledky ukazují, že $M$. mycoides využívá lipolytické enzymy $k$ degradaci lipidů nutných ke krytí energetických potřeb a $\mathrm{k}$ syntéze lipidové membránové vrstvy během multiplikace zárodků.

Kvantitativní stanovení a histochemické studie prokázaly vzestup aktivity aspartát-aminotransferázy (EC 2.6.1.1), alanin-aminotransferázy (EC 2.6.1.2), kyselé fosfatázy (EC 3.1.3.2), alkalické fosfatázy (EC 3.1.3.1), malátdehydrogenázy (EC 1.1.1.38), laktátdehydrogenázy (EC 1.1.1.27), adenosintrifosfatázy (EC 3.6.1.3) a amylázy (EC 3.2.1.1) v krevní plazmě, mléce a tkáních mléčné žlázy zřejmě v důsledku vzestupu celkového počtu leukocytů a zárodků $\underline{M}$. mycoides.

Биохимические изменения в кровяной плазме, молоке и тканях молочной железы овец после эксперименталыной инфекции Mycoplasma mycoides

Наблюдения за биохимическими изменениями в кровяной плазме, молоке и тканях молочной железы проводились у 7 лактирующих овец С односторонним маститом, экспериментально вызванным применением 2 мл кулытуры Mycoplasma mycoides subsp. mycoides (Mmm) типа крупных колоний (LC) с содержанием $10^{5}$ способных к воспроизведению клеток (CFU) в 1 мл. культуру М. mycoides вводили в канал соска правой половины молочной железы. Ее левая половина была контрольной. Каждые 3 сутки после инокуляции до 21 суток было умершвлено одно животное. У всех овец развился клинический мастит до 24 часов после инокуляции и длился до конца эксперимента. Концентрация общих белков, общего холестерина, фосфолипидов и несвязанных жирных кислот в молоке (или секрете молочной железыё прогрессивно увеличивалась, между тем как концентрация общих липидов и глицеридов сүщественно понижалась. Полученные 
данные свидетельствуют о том, что М. mycoldes использует липолитические энзимы для деградации липидов, необходимых для покрытия расхода энергии и синтеза липидного мембранного слоя в процессе мультипликации зародышей.

Количественные определения и гистохимические исследования выявили повьшение аспарат-аминотрансферазы (ЕС 2.6.1.1., аланин-аминотрансферазы (ЕС 2.6.1.2), кислой фосфатазы (ЕС 3.1.3.1), малатдегидрогеназы (ЕC 1.1.1.38), лактатдегидрогеназы (EC 1.1.1.27), аденозинтрифосфатазы (ЕС 3.6.1.3) и амилазы (ЕС 3.2.1.1) в кровяной плазме, молоке и тканях молочной железы, видимо, в результате увеличения общей численности лейкоцитов и зародьшей M. mycoides.

References

ADLER, H. E. - DAMASSA, A. J. -BROOKS, D. L.: Caprine mycoplasmosis: Mycoplasma putrefaciens, new cause of mastitis in goats. Am. J. Vet. Res., 41, 1980: 1677 - 1679 .

AGARWAL, V. K. - NARAYYAN, K. M.: Influence of mastitis on the physicochemical status of milk lipids. 1. Glycerides, free fatty acids and phospholipids. The Indian J. Dairy Sci., 29, 1976: 83 - 87.

AMES, B. N.: Assay of inorganic phosphate and phosphatases. In: Methods in Enzymology, Academic Press, New York, Vo1. 8, 1966, PP. 115 - 118.

BALL, H. J. - MACKIE, D. P.: Production of mastitis in ewes as a determinant of virulence of ovine ureaplasma strains. Vet. Microbiol., 10, 1985a: 117 - 123 .

BALL, H. J. - MACKIE, D. P.: The ovine mammary gland as an experimental model to determine the virulence of animal ureaplasmas., J. Hygiene., 95, 1985b: $375-382$.

BALL, H. J. - MACKIE, D. P.: Experimental production of bovine and ovine mastitis with Mycoplasma canadense isolate. Vet. Record., 118, 1986: 72 - 73.

BANERJEE, M. - SINGH, N. - GUPTA, P. P.: Isolation of mycoplasmas and acholeplasmas from pneumonic lesions in sheep and goats in India. $\mathrm{Zb1}$. Vet. Med. B., 26, 1979: 689 - 695 .

BARKA, T. - ANDERSON, P. J.: Histochemistry: Theory, Practice and Bibliography. Harper and Row Publishers Inc., New York, 1963.

BAR-MOSHE, B-RAPAPPORT, E.: Contagious agalactia like disease in goats caused oy Mycoplasma mycoides sub sp. mycoides (ovine/caprine) serotype 8. Refuah Veterinarith, 35, 1978: 75 - 77.

BARTON, M. D. - COTTEW, G. S.: Mycoplasmosis in goats. Aust. Vet. J., $\underline{56}$, 1980: 614 - 615 .

BENNET, R. H. - JASPER, D. E.: Immunologic and pathogenic response of cow to naturally occurring Mycoplasma bovis mastitis. Vet. Microbiol., $\underline{2}$, 1978: 325 - 334 . 
BOGIN, E. - ZIV, G. - AVIDAR, J.: Enzyme activites in normal and inflammed bovine udder tissues. Zentralblatt für Veterinamedizin., $\underline{6}, 1976: 460$ - 466.

CHERRY, J. D. - TAYLOR ROBINSON, D.: Mycoplasmas as Arthritogenic agents In: The Mycoplasmas. Vol. II., Human and Animal Mycoplasmas. Academic Press, New York, 1979: PP386.

COTTEW. G. S.: In: Mycoplasmas: Human and Animal Mycoplasmas ed. Tully and White comb. Academic Press, New York, 1979.

DAMASSA, A. J. - BROOKS, D. L. - ADLER, H. E.: Caprine mycoplasmosis; wide spread infection in goats with Mycoplasma mycoides sub sp. mycoides - (Large-colony type). Am. J. Vet. Res., 44, 1983: 322 - 325.

FOLCH, J. - LEES, M. - STANLEY, G. H. S.: A simple method for isolation and purification of total lipids from animal tissues. J. Biol. Chem., 226, 1957: 497 - 507.

GORNALL, A. G. - BRADWINN, C. S. - DAVID, M. M.: Determination of serum proteins by Biuret method. J. Biol. Chem., 177, 1949: 151

HEIDRICH, H. J. - RENK, W.: Diseases of mammary gland of domestic animals. W. B. Saunders Company, Philadelphia, London, 1967.

HORN, R. G. - SPICER, S. S. - WETZET, B. K.: Phagocytosis of bacteria by heterophil leucocytes. Am. J. Path., 45, 1964: $327-333$.

JAIN, N. C.: Alkaline phosphatase activity in leucocyte of some animal species. Acta Haemat., 39, 1968: 51 - 59.

JONE, G. E.: The pathogenicity of some ovine or caprine mycoplasmas in lactating mammary gland of sheep and goats. J. Com. Path., 95, 1985: $305-318$.

KANEKO, J. J.: Clinical Biochemistry of domestic animals. Academic Press, Inc. New York. 1980.

LEHNINGER, A. L.: Biochemistry. The Molecular basis of cell structure and functions. Kalyani Publishers, Ludhiana, New Delhi: 1982.

LOWRY, R. R. - TINSLEY, I. J.: Rapid Colorimetric determination of free fatty acids. J. Am. Oil. Chem. Soc., 53, 1976: 470 - 472.

MAMDAL, P. C. - AHUJA, S. P.: Observations on experimental mastitis in an Ewe and a goat induced by Klebsiella pneumoniae. Archiva Veterinaria. 17, 1985: $85-88$.

MANDAL, P. C. - RAHEJA, R. K.: Influence of mastitis on milk lipids in Indian buffaloes (Bubalus bubalis). Archiva Veterinaria, 17. 1985: 99 - 102 .

MANDAL, P. C. - SHARMA, D. R. - AHUJA, S. P.: Observations of a spontaneous case of fatal ovine mastitis due to Klebsiella pneumoniae. $\mathrm{Zbl}$. Vet. Med. B., 24, 1977: 168 - 174 .

MESZÁROS, M. J. - HORVÁTH, G. - STIPKOVITS, L. - VARGA, Z.: Gross and histopathological study of experimental Mycoplasma mastitis of cattle. Acta Veterinaria Hungarica., 34, 1986: $201-209$.

MISRI, J. - GUPTA, P. P. - AHUJA, S. P.: Biochemical changes in milk in experimental mycoplasmal mastitis in goats. Acta vet. Brno, 57, 1988: 19 -30 .

OJO, M. 0. - IKEDE, B. 0.: Pathogenicity of Mycoplasma agalactiae sub sp. bovis in goats mammary gland. Vet. Microbiol, $1,1976: \frac{19-22}{19}$

PAL, B. C. - SINGH, P. P. - PATHAK, R. C.: Mycoplasma bovigenitalium pathogenicity for caprine udder. Indian J. Comp. Micro. Imm. \& Infect. Diss. 4, 1983: 262 - 263. 
PRASAD, L. N. - GUPTA, P. P. - SINGH, N.: Experimental Mycoplasma arginini mastitis in goats. Aust. Vet. J., 62, 1985: 341 - 342 .

RANDOLPH, H. E. - ERWIN, R. E.: Influence of mastitis on properties of milk, fatty acid composition. J. Dairy Sci., 57, 1974: 865 - 868.

SCHALM, 0 . W.: Pathologic changes in milk and udders of cow with mastitis. J. Am. Vet. Med. Assoc., 170, 1977: 1137 - 1140.

SMITH, P. F.: The composition of membrane lipids and lipopolysaccharides. In: Mycoplasmas. Vo1. I, Ce11 Biology. Academic Press, New York. 1979. PP. $231-257$.

WILSON, R. - DOELL, B. H. - GROGER, W. - HOPE, J. - GELLATUS, J. B.: The physiology of liver enlargement. In: F. J. C. ed. Metabolic aspects of food safety. Black well scientific, Pub. Oxford. 1970: P. 363.

WOOTTON, I.D. P.: Microanalysis in Medical Biochemistry. J. and A. Churchill Ltd. , London. 1964.

ZLATKIS, A. - ZAK, B.: Study of new cholesterol reagent. Anal. Biochem. 29, 1969: 143 - 148 . 